\title{
The Influence of Transformational Leadership to Organizational Innovation and Explorative Learning Mediated by Generalist Human Capital at Oil Company
}

\author{
Putri Marina Sijabat*, Deasy Aseanty \\ Faculty of Economics and Business \\ Universitas Trisakti \\ Jakarta, Indonesia \\ *pmarina070297@gmail.com
}

\begin{abstract}
This study aims to analyse the effect of Transformational Leadership on Organizational Innovation and Exploration Learning mediated by the General Capital Human Oil Company. This research was conducted by distributing questionnaires to 150 respondents and the respondents were employees. Hypothesis testing is done by structural equation modelling (SEM) method with the help of AMOS software. The results of this study indicate that the average respondent agrees on each variable Transformational leadership, Organizational Innovation, Exploratory Innovation, Exploitative Innovation, Explorative Learning and Generalist Human Capital. In each item the statement shows that each item is declared valid and can be done to measure each research variable. The level of reliability shows that the Cronbach's Alpha of each variable is declared Reliable which means the respondent is consistent with his statement. The Generalist variable of Human Capital has not influenced fully to the effect of Transformational Leadership on Explorative Learning, the results of this study are also expected to be a reference for management and leaders to further enhance innovation in companies to be able to outperform manufacturing competition and human resources. In addition, the benefits of research are expected to be the basis for further research.
\end{abstract}

Keywords-transformational leadership, organizational innovation, explorative learning, exploratory innovation, exploitative innovation and general capital human

\section{INTRODUCTION}

In the current era of globalization, all companies are expected to provide the best performance to be able to compete with other companies. companies need Transformational Leadership to be able to encourage all employees to be motivated to always show the best performance and set a good example for all employees. Organizational Innovation makes a company able to compete superior in the era of globalization with a maximum with the company innovating in accordance with the conditions needed by the company. Explorative
Learning can be the best choice for a company's business, and coupled with a balance of knowledge and technology may be able to push the company beyond the desired target [1]. In this company there is a relationship between companies that focus on learning and organizational knowledge, where Human Capital plays a vital role. The better Transformational Leadership in a company, the better Organizational Innovation and Explorative Learning in the company which means that it shows that Generalist Human Capital is highly considered [2]. The general problem formulation of this research is "Is there an influence of Transformational Leadership on Oil companies on Organizational Innovation and Exploration Learning mediated by General Capital Human on Oil Company employees?". Research Objectives to analyse Transformational Leadership owned by oil companies, Organizational Innovation, Explorative Learning, General Human Capital, how much influence on Transformational Leadership on Organizational Innovation, the influence of Transformational Leadership on General Human Capital, the influence of Generalist Human Capital on Explorative Learning, the influence of Transformational Leadership towards Organizational Innovation mediated by Human Capital Generalists.

\section{LITERATURE REVIEW}

Transformational Leadership is a leadership style that supports employees, provides vision, meets expectations, encourages thinking more innovation and expands communication [3]. According to Transformational Leadership has several dimensions, namely Idealized Influence, Inspirational Motivation, Intellectual Stimulation, Individual Consideration [4]. Organizational Innovation is defined as the ability of a company to update ideas and knowledge into a new product, service or process mechanism [5]. Explorative Learning is an exemption for employees to seek knowledge in order to increase creativity at work, and be able to improve results for the company. Employees are also able to solve 
problems and find a way out of problems found in work by using knowledge that was previously obtained [6]. General Capital Human Capital is the accumulation of knowledge, skills, experience and other attributes of workers' strengths that are relevant in the strengths of an organization's employees and spur productivity and achievement of strategic goals [7].

A. The Effect of Transformational Leadership on Organizational Innovation and Explorative Learning mediated by the Human Capital Generalist $[8,9]$

H1: There is an influence of Transformational Leadership on Organizational Innovation

H1 a: There is an effect of Transformational Leadership on Exploratory Innovation

H1 b: There is an effect of Transformational Leadership on Exploitive Innovation

$\mathrm{H} 2$ : There is an influence of Transformational Leadership on Generalist Human Capital

H3: There is the influence of the Generalist Human Capital on Explorative Learning

H4: There is an influence of Transformational Leadership on Explorative Learning mediated by General Capital Human

H5: There is an influence of Transformational Leadership on Explorative Learning

\section{METHODS}

This study was modified from the research entitled "Human capital: The Link Between Leadership and Organizational Learning" [8] and the research entitled "The Role of CEO Transformational Leadership and Innovation Climate in Exploration and Exploitation" [9]. This study was conducted to determine the effect of Transformational Leadership on Organizational Innovation and Explorative Learning mediated by the General Capital of Human Capital on employees in the Oil Company with a number of questionnaires given to 150 employee and research was conducted by way of questionnaire dispensing with the units used in this study using hypothesis testing or hypothesis testing, explaining the difference in the nature of a form or a relationship between independence or more than two independencies or differences between groups in a situation [10]. This study uses cross sectional data method because the data is taken only once with the time specified in answering the questionnaire given to employees [11]. The independent variable in this study was conducted by Zuraik and Kelly who said that Transformational Leadership is an independent variable [9]. Intervening Variable in this study conducted by Ma Dolores is the Generalist of Human Capital [8]. In the study conducted by Zuraik and Kelly who said that Organizational Innovation is a dependent variable, namely Explorative Innovation and Exploitative Innovation [9]. Explorative Learning included in the dependent variable in this study was conducted by Zuraik and Kelly Data collection was carried out to obtain the information needed in order to achieve the research objectives, the objectives expressed in the form of hypotheses were temporary answers to research questions [9]. The data source used in this study is primary data by distributing questionnaires which are then filled out by respondents. This questionnaire which contains a list of questions that will be answered by respondents, respondents will be asked for a conscious statement without coercion in accordance with their opinions.

\section{RESULTS AND DISCUSSION}

\section{A. Result}

The validity test results of the Transformational Leadership variables studied were obtained significant values of more than 0.45 , which means each of these variables is valid. validity testing results note that the Generalist Human Capital variable is declared valid because the results of factor loading values are greater than 0.45 and can be used for further analysis. Exploratory Innovation and Exploitative Innovation results above 0.45 , which means it can be used for further analysis. Explorative Learning variable is valid, the result of factor loading is above 0.45 which means that each item of statement used to measure the exact variable and can be used for further analysis. Explorative Learning variable is valid, the result of factor loading above 0.45 which means that each item of statement used to measure variables precisely and can be used for further analysis [12]

The reliability test is a measurement in the study which shows how far the measurement is without error therefore this test guarantees consistent measurements in the instrument, the Cronbach's Alpha Transformational Leader variable in this study 0.795 means that it meets the reliability criteria or can be said to be acceptable. So that respondents' answers to the statements used to measure variables can be said to be consistent respondents. Then Cronbach's Alpha Generalist Human Capital variable in this study 0.770 means that it has met the reliability criteria. Cronbach's Alpha for the Exploratory Innovation and Exploitative Innovation variables of 0.726 and 0.706 thus that Explorative Innovation and Exploitative Innovation can be said to meet the reliability criteria. While Cronbach's Alpha on the Explorative Learning variable is 0.828 , which means it meets the reliability criteria [13].

\section{B. Discussion}

The results of the descriptive statistical analysis of the Transformational Leadership variable, it is known that the average value is 4.338. This shows that having a Transformational Leadership style that supports positive things for the company, the leader never does the distance between superiors and ordinary employees. Descriptive statistical analysis results of the Generalist Human Capital variable, it is known that the average value is 4.160 , which means this shows that the average respondent gave an answer agreeing that the Generalist Human Capital has been going well. The results of the descriptive statistical analysis of Exploratory Innovation variables have an average of 4.287 which means that it means that employees agree that they have the desire to look for new technology ideas and learn the process of developing new products so able to create creativity that is able to increase customer satisfaction and trust. The results of descriptive statistical analysis of exploitative innovation variables which have an average of 4,417 which means employees agree that all employees try to improve and perfect existing products so that they are able to be widely accepted by the market. The company also streamlines existing products and services, in 
order to be able to increase economies of scale in the market. The highest value of the exploitative innovation variable is 4,527 , which means employees agree that the Oil Company has increased economies of scale in the existing market. The results of the first hypothesis testing are to test the Transformational Leadership effect on Organizational Innovation with a significant value and p-value of $0,000<0.05$ with an estimated value of 0.907 . This shows that a leader who has a transformation in leading will generate good energy to the innovations produced by these employees. The results of testing hypothesis $1 \mathrm{a}$ is testing the Transformational Leadership effect on Exploratory Innovation with a significant p-value of $0,000<0.05$ with an estimated value of 0.495 . This shows that a leader who has a transformational spirit will influence the innovation of employees to create new things that have never before existed. The results of testing hypothesis $1 \mathrm{~b}$ is testing the Transformational Leadership effect on Exploitive Innovation with a significant $p$-value of $0,000<0.05$ with an estimated value of 0.965 which means that Oil Company has a leader whose transformational spirit influences employees in terms of innovation so that products / services that Oil Company already has are still able to direct the company to better things. The results of testing the next hypothesis is to test the influential Transformational Leadership of the General Capital of Human Capital which has a significant p-value of $0,000<0.05$ with an estimated value of 0.171 . This shows that there is a positive and significant effect thus there is the influence of a transformational leader with employees who have a thorough knowledge of the company. The results of testing the hypothesis that tests the Generalist Human Capital influence on Explorative Learning has a significant p-value of $0,000<0,05$ and an estimated value of 0.869 , this shows that employees who have the desire to gain more knowledge will make the employee able to master all things related to progress support. The results of the final hypothesis testing are testing Transformational leadership towards Explorative learning mediated by the Generalist Human Capital has an estimated value of 0.457 and a significant p-value of 0,000 and compared directly with transformational leadership towards Explorative learning is significant with a p-value of 0,000 and an estimated value of a similar $r 0.859$. So this shows that the presence or absence of a Human Capital Generalist in the Oil Company, does not affect greatly, employees will continue to learn the knowledge widely to support a career in the company.

\section{CONCLUSION}

Find out whether the same phenomenon also occurs in other companies and so that the samples used are far more so that this research can continue to develop even better with the suggested new framework. Add several related variables such as work involvement, organizational commitment, and job satisfaction. So that it can produce varied research with new findings and is needed to support the results of research on other research objects. Respondents in further research are expected to be expanded.

\section{REFERENCES}

[1] W. Vanhaverbeke, B. Beerkens, G. Duysters and V. Gilsing, "Explorative and exploitative learning strategies in technology-based alliance networks," Ecis (Eindhoven Center for Innovation Studies) Working Paper, 2003

[2] D.P. Lepak and S.A. Snell, "Examining the human resource architecture: The relationships among human capital, employment, and human resource configurations," Journal of management, vol. 28, no. 4, pp. 517-543, 2002.

[3] F. Bushra, A. Usman and A. Naveed, "The effect of transformational leadership on employees' Job satisfaction and organizational commitment in the Banking Sector of Lahore (Pakistan)," International Journal of Business and Social Science, vol. 2, no. 18, pp. 261-268, 2011.

[4] A. Usair and Y. Kyung Bae, "The impact of transformational leadership style on innovation as perceived by public employees in Jordan," International Journal of Commerce and Management, vol. 22, no. 3, pp. 182-201, 2012.

[5] A. Ilsev and L. Gumuslooglu, "Transformational Leadership Creativity and Organizational Innovation,” Journal of Business Research, pp. 461473, 2009.

[6] Trisna Nugraha, Explorative Approach and Savi Approach. Indonesian education university, 2018.

[7] J. Matthewman and F. Matigon, Human Capital Internal Reproductive Perspective. London: CIPD and Mercer Human Resource Consulting, 2004.

[8] Ma dolores de la Rosa-Navarro, Human Capital: The link between leadership and organizational learning, 2019.

[9] A. Zuraik and L. Kelly, The role of CEO in transnational leadership and innovation climate in exploration and exploitation, 2019.

[10] H. Hermawan, Analysis of the Effect of Job Satisfaction and Karywan's Commitment to Organizations on the Desire to Change Work. University of Indonesia: Depok, 2013.

[11] U. Sekaran and R. Bougie, Research methods for business. West Sussex: John Wiley \& Sons, 2010.

[12] O. Olaniyan and O. Okemakinde, "Human Capital Theory: Implications for Educational Development," European Journal of Scientific Research, vol. 24, no. 2, pp. 157-162, 2008.

[13] N. Sahaya, "The Implementation of Learning Organization as A Mediatior of Leadership Style and Firm's Financial Performance,' International Journal of Business and Management, vol. 7, no. 14, pp. 96-113. 